\title{
Article
}

\section{The Leadership Role of Psychiatrists in the NHS}

Willcocks, Stephen George

Available at http://clok.uclan.ac.uk/15502/

Willcocks, Stephen George ORCID: 0000-0002-1764-5951 (2016) The Leadership Role of Psychiatrists in the NHS. British Journal of Healthcare Management, 22 (9). ISSN 1358-0574

It is advisable to refer to the publisher's version if you intend to cite from the work. 10.12968/bjhc.2016.22.9.455

For more information about UCLan's research in this area go to http://www.uclan.ac.uk/researchgroups/ and search for < name of research Group>.

For information about Research generally at UCLan please go to http://www.uclan.ac.uk/research/

All outputs in CLoK are protected by Intellectual Property Rights law, including Copyright law. Copyright, IPR and Moral Rights for the works on this site are retained by the individual authors and/or other copyright owners. Terms and conditions for use of this material are defined in the policies page.

\section{CLoK}

Central Lancashire online Knowledge www.clok.uclan.ac.uk

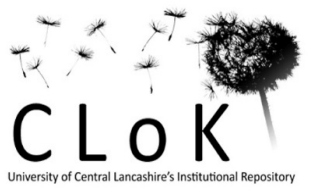




\section{The Leadership Role of Psychiatrists in the UK NHS}

Success in the NHS is said to depend on the continuing engagement of doctors with leadership, (Brown and Brittlebank, 2013, p30). This has been generally recognised by policy makers in recent years as witnessed by various reports such as the Darzi, (2008), Keogh, (2013), Berwick, (2013), and Francis reports (2013). One reason is the 'positive link between engagement of clinicians in leadership and improved patient care'. (Garg, et al, 2011, p163).

The aim of this paper is to explore the engagement of doctors with leadership in a specific context, namely, psychiatry. Firstly, it looks at the policy context and the background to leadership; secondly, it discusses the applicability of a specific approach to leadership in the context of psychiatry; and thirdly, it makes recommendations about how to develop leadership in this context.

\section{Policy context}

Psychiatry faces considerable policy challenges, not least because it 'straddle[s] healthcare, primary and acute care, as well as social care', (Brown and Brittlebank, 2013, p30), all of which are undergoing transformational change as part of recent Government policy. With regard to mental health services, there is a recognition by policy makers of the fact that such services have been neglected historically. In fact, mental illness is the largest cause of disability yet only $13 \%$ of NHS spending is devoted to treatments for mental illness, (NHS England, 2014, p26).

Government policy is to upgrade quality and access to mental health services, in order to combat longstanding concern about disparity in provision of services, (NHS England, 2015). Mental health services are to be transformed to bring them at least up to par with other healthcare services, with a goal to achieve parity between physical and mental health by 2020, (NHS England, 2014).

This transformation process will be led by local commissioners ie CCGs (Clinical Commissioning Groups), but the Government intends to use other sources such as the creation of a new cross system task force to develop vision and strategy for mental health services, (NHS England, 2015 ). . The Government envisages whole system changes to the pattern of health and social care in the future. Clinical leadership will be key to implementing such changes at both local and national levels. Psychiatrists may be involved in this in leadership roles such as team leader, clinical director or medical director or members of clinical networks.

Organisations delivering mental health services such as NHS Trusts, community mental healthcare teams, or specialist psychiatric units will be transformed as a result of the changes. The government acknowledges that the policy of 'one size fits all' is no longer appropriate, and proposes to explore new models of delivery which facilitate integration of services such as the New Care Models programme. Mental health services feature in the new care models initiative. One model is the vertically integrated GP and hospital service, with primary and secondary care provided by one organisation. Several providers have already been authorised to develop 'van guard' sites for such integrated primary, and acute care systems, joining up GP, hospital, community and mental health services.

More generally, changes to service delivery mean that 'nearly all psychiatric specialties now involve substantial elements of work outside the hospital' and there are challenges, not least for leadership, in delivering combined hospital and community services, (Linsley et al, 2001, p208).

The policy context for mental health service is likely to be subject to considerable change over the next few years although this will be in the context of continuing budgetary constraint and any change of policy resulting from the political decision making process. Leadership of these changes 
has not always been evident at clinical levels in psychiatry but it will become increasingly necessary for clinicians to get involved..

\section{Leadership in psychiatry}

Leadership is a highly contested field of study. There are many approaches which may be explored including traits or personality theory, style theory, contingency/ situational leadership, servant leadership, authentic leadership and new paradigm models, such as transformational leadership, or charismatic leadership, to name the more well- known approaches. More recent approaches have focused on shared or distributed leadership. In the NHS, the competency based approach has been popular in recent years and a variety of competency frameworks have been devised including one specifically for doctors, the Medical Leadership Competency framework. In the latter, individual competencies are central to the influence process.

This paper is not intended to be a critical review of these different leadership theories. Rather, it takes up the suggestion by Corrigan et al, that one of these- transformational leadership- may be relevant and worth exploring in the mental healthcare setting, (Corrigan, et al, 2000, Corrigan, et al, 2003). In fact, numerous studies have applied the approach to this setting, (eg Corrigan, et al, 2003, Green et al, 2013, Aarons, 2006).

While there are many alternatives, transformational leadership is said to be: 'the most thoroughly researched approach to leadership' with considerable validity across organisations and in different countries, (Green et al, 2013, p377). It is also of interest because of its focus on both the leaders skills and the impact on followers, (Hartley and Benington, 2010, p86). In general terms it is defined as:

'a process that changes and transforms individuals, it....involves an exceptional form of influence that moves followers to accomplish more than what is usually expected of them', (Northouse, 2004, p169).

The emphasis on the process of change makes it particularly of interest to psychiatry in the current policy context, although the extent to which followers are willing to go beyond what is expected of them is debateable. It is consistent with general definitions of leadership such as the definition of leadership as an influence process involving both the individual leader and the process of interaction with followers, (Northouse, 2004, p3).

Transformational leadership is based on specific leadership behaviours that may be used in the influence process, (Hartley and Benington, 2010, p86). It consists of four sets of behaviours or leadership factors ie idealised influence, inspirational motivation; intellectual stimulation; and individualised consideration, alongside separate factors for transactional leadership, (Northouse, 2004, p175). The first two are intended to identify a 'desirable future' that followers aspire to; intellectual stimulation encourages innovative and creative behaviour; and individualised consideration is about developing, and supporting followers, (Bass, 1999, p11).

It can be argued that each of these has relevance to leadership in psychiatry. For example, psychiatrists need to be involved in formulating the future state or vision for mental health services; they need to be creative and innovative in the planning and delivery of such services; and they need to adopt a supportive style of leadership that is compatible with the nature of those involved in psychiatry. With regard to the latter, individual consideration is a particularly relevant leadership behaviour, and is likely to resonate with the ethos in psychiatry. Both leadership and clinical situations in psychiatry have an emphasis on listening to people, and taking appropriate action 
tailored to individual needs. In leadership situations it means acknowledging 'followers' individual differences', (Stone, et al, 2004, p351).

Together, these behaviours contribute to the leaders' ability to influence or bring about change by utilising individual characteristics, such as charisma; behaviours- such as acting as a role model, communicating expectations, and motivating and stimulating followers; and by providing a supportive environment, (Northouse, 2004, p175-177). The overall intention is to engage colleagues and ensure they are committed to the change agenda and also motivated to improve performance, (Hartley and Benington, 2010, p87). This is an important aspect of clinical leadership and is needed to address the problem of lack of clinical engagement that has been a feature of the NHS in recent years, (Ashman and Willcocks, 2014).

Other advantages of transformational leadership include its effect in minimising burnout and developing a supportive organisational culture, (Corrigan, et al, 2003, p105). Given the extent of change in mental health services this may also be a significant. Indirectly, transformational leadership may have a mediating effect on problems of emotional exhaustion, it may contribute to developing group cohesion, organisational commitment and recognising and rewarding team members, (Green et al, 2013, p374). Transformational leadership has also been found to act as a buffer against workplace stress, improving staff retention and contributing to the 'quality and outcomes of mental health services', (Green et al, 2013, p378). All of these effects can be said to apply to psychiatry given the high intensity and stressful nature of the work in this specialty.

However, transformational leadership is not without criticism. Some observers have noted it may not be suitable across all cultures, it is biased towards white male leaders, and it tends to focus on top leaders ie distant leadership, (Alimo- Metcalfe et al, 2007, p22). While a lot rests on the possession of personal qualities such as charisma, there may be problems when there are flaws in these personal qualities. This has been described as 'the dark side of charisma', (Alban- Metcalfe and Alimo- Metcalfe, 2009, p11).

There are potential problems with the fact that transformational leadership is focused on distant leaders. In the NHS - and generally- there is increasing attention on the need for 'nearby' leadership, and on an engaging style of leadership. A UK study by Alimo-Metcalfe and Alban- Metcalfe found similarities with the US version of transformational leadership but in their version of nearby transformational or engaging leadership they also identified differences, in particular, more emphasis on 'genuine concern for others' well- being and development' (similar to 'individual consideration'), with less attention on charisma, (Alimo- Metcalfe, et al, 2007, p25-26). What is required in their view is an engaging style of leadership, in which the leader is defined as:

'someone who encourages and enables the development of an organisation that is characterised by a culture based on integrity, openness, and transparency, and the genuine valuing of others' (AlbanMetcalfe and Alimo- Metcalfe, 2009, p13).

This focus is said to be akin to the idea of servant leadership, (Alimo-Metcalfe and Alban-Metcalfe, 2005 , p62). The latter is about serving the needs of others, and is said to have 'strong altruistic ethical overtones', (Northouse, 2004, p309). In fact, transformational leadership and servant leadership are said to be complementary, in that the former focuses on achieving organisational objectives and the latter on followers, (Stone,et al, 2004, p359). Psychiatrists may find this combination relevant to their context, given the need to focus on inspiring followers to change, and, at the same time, understanding individual needs, providing empathy and support, and empowering followers, (Gopee and Galloway, 2009, p57). 
What is needed in psychiatry may be a variant that allows for the fact that leadership focuses as much on achieving objectives as on showing genuine concern for followers. Given problems of clinical engagement in the NHS, the latter is particularly important. A version is also needed that is compatible with the particular requirements and context of clinical leadership, taking cognizance of the fact that it is a professional service -oriented context wherein those involved have some degree of autonomy. It is important to recognise that leadership is a 'collective cultural activity' shared or distributed across the organisation, consistent with clinical leadership in the NHS, (Edmonstone and Western, 2002, p36). There are implications in implementing this.

\section{Implications and recommendations}

It is suggested that psychiatrists start with certain advantages with regard to developing their leadership role, (Craddock et al, 2010, Denny, 2000). They are said to have the right balance between training and personality to make them better equipped than other specialities to take on such a role, (Bickel, 2007, p1). For instance, they are likely to have developed emotional intelligence in their clinical practice which may be transferable to their leadership role. Possession of emotional intelligence by psychiatrists may enhance their ability to engage with transformational leadership. In fact, empirical research has shown that emotional intelligence is linked to the behaviours associated with this approach, (Barling et al, 2000, pp159). It is said that leaders who are 'high in emotional intelligence would be more likely to use transformational behaviours', (Barling et al, 2000, pp 157). Some have suggested emotional intelligence is more important for leadership than intelligence, (IQ), or specific personality traits, (Rosete and Ciarrochi, 2005, p388). Emotional intelligence is developed in psychiatric training and practice through the process of autognosis, that is the process of understanding self, and ones feelings, (Johnson and Stern, 2013, p299). It is said that, 'no other field of medicine provides as rigorous an emphasis on self- awareness as does psychiatry', (Johnson and Stern, 2013, p299). These advantages may be relevant in terms of developing transformational leadership skills and behaviours.

In terms of developing leadership it is noted that it is now part of core training in psychiatry. The specialty requires trainees to develop relevant leadership skills such as communication, leadership and team building skills, (Garg, et al, 2011, p164). It is suggested that there is a need for leadership development to be done early on in a psychiatrists' career path, and not just by 'training on the job', (Buckley, 2009, p 402). Buckley states that leadership development may be a combination of 'on the job', and 'off the job' via formal training, for example, in higher training posts, and by continuing professional development opportunities, (Buckley, 2009, p402).

It may be nurtured and developed via experiential learning, with the opportunity for reflection on the leadership role, (Bryson and Asher, 2008, p189). Garg et al, 2011 note that such experiential learning might be acquired by psychiatrists at several levels, such as corporate trust level; directorate level; and individual levels, with the latter also involving the acquisition of knowledge about leadership,(Garg et al, 2011, p165). Work based learning has become popular in the NHS and may be relevant, with the use of coaching, mentoring, project work, and learning from temporary roles such as acting up and job rotation, (Edmonstone and Western, 2002, p37).

As noted by Oakley, et al, 2013, any leadership development would have to take into account current moves to implement a competency approach for doctors, such as the medical leadership competency framework, and its use by the Royal College of Psychiatry in its training curriculum, (Oakley, et al, 2013, p27). In fact, the medical leadership competency framework has been implemented in the revised curriculum for psychiatric specialist training, with leadership specifically mentioned as a learning outcome, (Garg, et al, 2011, p163). While competencies are relevant and 
provide for specific activities, there is nevertheless a need for an overarching approach or focus to leadership such as transformational leadership.

A key emphasis would be on identifying and developing skills and behaviours that enable psychiatrists to influence the change agenda and bring about change, (Willcocks, 2016 p12). Buckley notes that ' a leader needs to be able to lay out a vision and to bring people along towards that vision', (Buckley, 2009, p402). This may be nurtured by individualised training or coaching, with due attention being given to feelings, emotion and so forth, (Willcocks, 2016, p11). ). Psychiatrists may have an advantage in that are able to tolerate the disorder which comes with leading change, their training as psychiatrists enables a 'high tolerance for ambiguity, ambivalence and disorder', (Wilson, 2000, p5).

Regardless of approach to development, an overriding concern will be to ensure that psychiatrists are fully engaged with leadership and provided with adequate support and resources.

\section{Conclusion}

This paper has explored leadership in the context of psychiatry in the UK. It has reviewed the policy context and identified challenges that are likely to present to clinical leaders. While psychiatrists may possess certain advantages resulting from their clinical work and experience, nevertheless, they may gain benefit by exploring the value of a transformational leadership model.

The latter is a well -known and popular model which has been applied to NHS settings and has been seen to be useful as a way of analysing the appropriateness of various leadership behaviours. It can be noted, however, that transformational leadership is only one way of many different approaches to leadership. Nonetheless, it has been popular and relevant in healthcare, particularly given the extent of change in the NHS.

\section{References}

Alban- Metcalfe, J and and Alimo- Metcalfe, B (2009) Engaging leadership part one: competencies are like Brighton pier, International Journal of Leadership in Public Services 51 pp10-18

Alimo-Metcalfe, B and Alban-Metcalfe, J (2005), Leadership: a time for a new direction? Leadership, Vol1 (1) pp51-71

Alimo- Metcalfe, B, Alban- Metcalfe, J, Samele, C, Bradley, M and Mariathasan, J, ( 2007), The impact of leadership factors in implementing change in complex health and social care environments: NHS Plan clinical priority for mental health crises resolution teams, London, HMSO

Aarons, G A, ( 2006), Transformational and transactional leadership: association with attitudes toward evidence based practice, Psychiatric Services, August, Vol 57, 8 pp 1162-1169

Ashman, I and Willcocks, SG,(2014), Engaging with clinical commissioning: the attitude of GPs in East Lancashire, Quality in Primary Care, Vol 22, 2 pp91-98

Barling, J, Slater, F, Kelloway, K (2000), Transformational leadership and emotional intelligence; an exploratory study Leadership and Organisation development Journal, Vol 213 pp 157-161

Bass, B (1999) Two decades of research and development in transformational leadership, European Journal of Work and organisational Psychology, 8, 1 pp9-32

Berwick , D, (2013), A promise to learn, a commitment to act: improving the safety of patients in England, DOH, London 
Bickel, J (2007) Turning intellectual capital into leadership capital: Why and how Psychiatrists can take a lead, Academic Psychiatry, Jan/Feb 311 pp1-4,

Brown, N and Brittlebank, A ( 2013), How to develop and assess the leadership skills of Psychiatrists, Advances in Psychiatric treatment, Vol 19, pp 30-37

Bryson, S and Asher, C J (2008), building capacity for leadership and teamwork: developing, delivering and evaluating an experiential group relations conference, Psychiatric Bulletin, 32 pp189192

Buckley, P F, Editorial,(2009), Leadership development: more than on the job training, Psychiatric Bulletin 33 pp $401-403$

Corrigan, P W, Lickey, S E, Campion, J and Rashid, F, (2000), Mental health team leadership and consumers satisfaction and quality of life, Psychiatric Services, June 6 pp781-785

Corrigan, P W, Diwan, S, Campion, J, and Rashid, F (2003) Transformational leadership and the mental health team, Administration and Policy in Mental Health Vol 30, 2 November, pp97-108

Craddock, N, Kerr, M and Thapar, A,( 2010), What is the core expertise of the psychiatrist? The Psychiatrist, 34 pp457-460

Darzi, A, (2008), High quality care for all: NHS next stage review, final report, DOH, London

Edmonstone, J and Western,J ( 2002), Leadership development in healthcare: what do we know? Journal of Management in Medicine, Vol 161 pp34-47

Francis, R, (2013), Report of the mid Staffordshire NHS foundation trust public inquiry, Stationery office, London

Garg, S, van Niekerk, J, and Campbell, M ( 2011), Medical leadership: competencies in action, Advances in Psychiatric Treatment, 17 pp162-170

Gopee, N and and Galloway, J ( 2009), Leadership and management in healthcare, Sage, London

Green, A E, Miller, E A, and Aarons, G A, ( 2013), Transformational leadership moderates the relationship between emotional exhaustion and turnover intention among community mental health providers, Community Mental Health Journal, 49 pp 373-379

Hartley, J and Benington, J (2010), Leadership for healthcare, The Policy Press, Bristol

Johnson, J M, and Stern, T A, (2013), Preparing psychiatrists for leadership roles in healthcare, Academic Psychiatry, 375 pp 297-300

Keogh, B, (2013), review into the quality of care and treatment provided by 14 hospital trusts in England, overview report, DOH, London

Linsley, K, Slinn, R, Nathan, R, Guest, L, and Griffiths, H (2001), Training implications of communityoriented psychiatry, Advances in Psychiatric Treatment, May 7 (3) pp208-215

NHS England (2015) Building the NHS of the Five year Forward View, NHS England Business Plan, Leeds

NHS England, (2014), Five Year Forward View, October, Leeds

Northouse, P G, ( 2004), Leadership: theory and practice, Sage London 
Oakley, C, Jenkinson, J and Oyebode, F, (2013), Psychiatric training for the next generation, The Psychiatrist, 37, pp25-29

Rosete, D, and Ciarrochi, J, (2005), Emotional intelligence and its relationship to workplace performance outcomes of leadership effectiveness, Leadership and Organisation Development Journal, Vol 26, 5 pp 388-389

Stone, A G, Russell, R F, and Patterson, K ( 2004), Transformational versus servant leadership: a difference in focus, Leadership and Organisation Development Journal, 25, 4 pp 349-361

Willcocks, S G, (2016), Exploring leadership in the context of dentistry in the UK, Leadership in Health Services, 292 pp1-16

Wilson, J, ( 2000), The flight of the wild goose: the psychiatrist as a leader, Australian and New Zealand Journal of Psychiatry, 34 pp1-7 